Volume: 7

Nomor : 1

Bulan : Februari

Tahun : 2021

\title{
Upaya Meningkatkan Hasil Belajar IPA melalui Penggunaan Media Komputer Interaktif dan Metode Demonstrasi
}

\author{
Nur Aisyah \\ Yuyun Supriyani \\ Neneng Hawaliyah \\ Universitas Muhammadiyah Prof. Dr. HAMKA \\ Pos-el: aisyahnur808@gmail.com \\ yuyun_syifa@yahoo.com \\ nayawal6@gmail.com
}

DOI: $10.32884 /$ ideas.v\%vi\%i.323

\begin{abstract}
Abstrak
Hambatan dalam pembelajaran IPA umumnya terletak pada penggunaan media dan metode pembelajaran yang kurang menarik, menantang, dan menyenangkan, sehingga rata-rata hasil belajar masih di bawah kriteria ketuntasan minimal (KKM). Oleh karena itu, penelitian ini bertujuan untuk meningkatkan kualitas pembelajaran IPA melalui penggunaan media komputer interaktif dan metode demonstrasi. Penelitian ini merupakan penelitian tindakan (action research) yang dilaksanakan di kelas IV SDN Semper Timur 07 Jakarta Utara. Penelitian ini terdiri dari dua siklus. Berdasarkan hasil penelitian, hasil belajar, dan keaktifan siswa dalam belajar mengalami peningkatan sejak tahap prasiklus hingga berakhirnya siklus 2. Dari $23 \%$ yang mengalami ketuntasan pada tahap prasiklus, menjadi $73 \%$ pada siklus 1 , dan $95 \%$ pada siklus 2 , serta siswa terlibat secara aktif dalam pembelajaran. Dengan demikian, dapat disimpulkan bahwa penggunaan media komputer interaktif dan metode demonstrasi pada pembelajaran IPA dapat meningkatkan hasil belajar dan siswa terlibat secara aktif dalam pembelajaran.
\end{abstract}

\section{Kata kunci}

Hasil belajar IPA, media komputer interaktif, dan metode demonstrasi

\begin{abstract}
Barriers to learning science generally lie in the use of media and learning methods that are less attractive, challenging and fun, so that the average learning outcomes are still below the Minimum Completeness Criteria (KKM). Therefore, this study aims to improve the quality of science learning through the use of interactive computer media and demonstration methods. This research is an action research conducted in class IV SDN Semper Timur 07 North Jakarta. This study consisted of 2 cycles. Based on the results of the research, learning outcomes and student activity in learning have increased from the pre-cycle stage to the end of cycle 2 .From $23 \%$ who completed the pre-cycle stage, to $73 \%$ in cycle 1, and $95 \%$ in cycle 2 , and students were actively involved in learning. Thus, it can be concluded that the use of interactive computer media and demonstration methods in science learning can improve learning outcomes and students are actively involved in learning.
\end{abstract}

Keywords

Science learning outcomes, interactive computer media, and demonstration methods

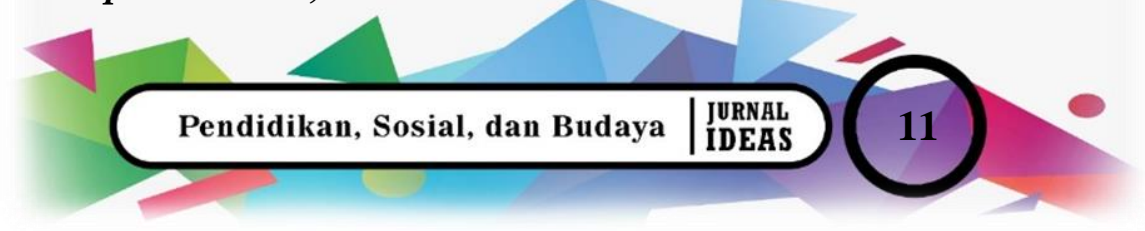




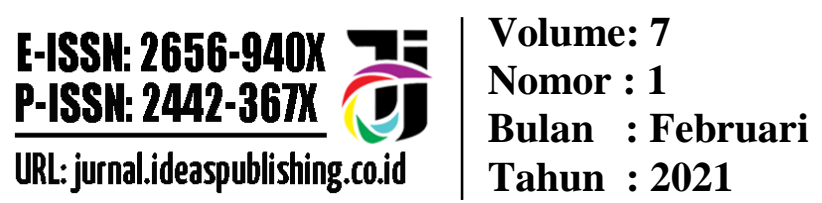

\section{Pendahuluan}

Peranan teknologi di masa digital dapat dimanfaatkan secara optimal untuk mendukung proses pembelajaran khususnya dalam proses pendidikan, sehingga bisa menunjang guru di dalam mengemas serta menyajikan data kepada siswa (Dwiqi dkk., 2020). Saat ini, era digital memberikan dampak yang sangat besar dalam kehidupan manusia, sehingga tidak bisa dipandang sebelah mata khususnya oleh dunia pendidikan (Widiara, 2018).

Pemanfaatan media dalam pendidikan bisa membangkitkan minat baru, menambah motivasi, dan meningkatkan rangsangan aktivitas belajar, serta dapat memberikan pengaruhi secara psikologis kepada siswa (Putra \& Ishartiwi, 2015). Sayangnya penggunaan teknologi digital di dalam menunjang proses pembelajaran belum diterapkan secara maksimal. Hal ini disebabkan oleh beberapa kendala seperti memilih ataupun merancang media pembelajaran yang sesuai dengan materi pembelajaran; mengoperasikan media pembelajaran berbasis IT, dan lain-lain. Hal tersebut menyebabkan kurang menariknya proses pembelajaran, sehingga menyebabkan kurangnya pengalaman belajar siswa. Dengan demikian, tujuan pembelajaran tidak dapat tercapai secara maksimal.

Rusdewanti \& Gafur (2014) juga menyatakan bahwa masalah yang dialami sekolah dalam pemanfaatan media saat ini adalah kurang tersedianya media pendidikan interaktif di sekolah. Fungsi utama media pendidikan adalah sebagai perantara yang dapat menyampaikan pesan atau informasi. Media pendidikan dapat mendukung dan memberikan dampak yang baik dalam meningkatkan kualitas pembelajaran, memotivasi belajar siswa, dan meningkatkan rasa emosional dengan melibatkan siswa secara langsung dalam penggunaannya (Astra dkk., 2013; Hartini dkk., 2017; Rahmi dkk., 2019)

Potensi diri siswa yang dikembangkan akan berjalan lebih efektif apabila pendidik memanfaatkan media pendidkan yang tepat (Fauyan, 2019; Widiana dkk., 2015). Seorang pendidik harus memiliki kemampuan dalam membuat maupun mengembangkan media pendidikan, baik yang menggunakan teknologi maupun tidak (Oktafiani dkk., 2020). Salah satu faktor yang turut menentukan keberhasilan pengajaran adalah dalam penggunaan media, karena dapat memudahkan siswa dan guru dalam menyampaikan materi pembelajaran terkait dengan tujuan pembelajaran (Hartini dkk., 2017; Pamungkas dkk., 2018). Multimedia dapat menciptakan pembelajaran yang aktif bagi peserta didik sehingga mempengaruhi daya pikir siswa (Nopriyanti \& Sudira, 2015; Prasetyo \& Prasojo, 2016). Secara konseptual, dua unsur 


\section{Volume: 7 \\ Nomor : 1 \\ Bulan : Februari \\ Tahun : 2021 \\ E-ISSH: 2656-940X P-ISSH: 2442-367K \\ URL: jurnal.ideaspublishing.co.id}

yang dipresentasikan oleh multimedia yaitu teks berupa lisan atau tercetak, dan gambar berupa ilustrasi, foto, animasi, atau video (Praditya, 2019; Prasetyo \& Prasojo, 2016).

Upaya yang dapat dilakukan untuk meningkatkan hasil belajar siswa diantaranya adalah dengan mengoptimalkan penggunaan media pembelajaran. Namun kenyataannya, terjadi kesenjangan antara kemampuan guru dalam menggunakan media dengan metode yang sesuai dengan karakteristik siswa yang aktif dan memiliki rasa ingin tahu yang tinggi.

Sutarman (2016) menjelaskan salah satu cara mengatasi masalah dalam pembelajaran IPA adalah dengan memberikan berbagai informasi dan pengetahuan konsep yang tidak hanya dalam bentuk tekstual tetapi juga visual, konsep, dan kinestetik dalam setiap proses belajarnya. Hermawan (2009) mendefinisikan pembelajaran berbasis komputer dengan model tutorial merupakan program pembelajaran yang memanfaatkan perangkat lunak, berupa program komputer yang berisi materi pelajaran. Tujuan dari pengajaran tutorial adalah untuk memberikan pemahaman secara tuntas kepada siswa, mengenai materi atau bahan pelajaran yang sedang dipelajarinya.

Metode yang digunakan dalam pembelajaran dengan memanfaatkan media komputer interaktif pada penelitian ini, adalah metode demonstrasi. Metode demonstrasi adalah peragaan terkait proses terjadinya suatu peristiwa atau benda sampai pada penampilan tingkah laku yang dicontohkan, agar dapat diketahui dan dipahami oleh siswa baik secara nyata atau berupa tiruannya (Sagala, 2006).

Hasil penelitian terdahulu menunjukkan bahwa,

"It is concluded that simulations play an important role in enhancing student performance by offering an immersive experience on the basis of the contrast between control and experimental groups in three key areas, i.e., written, viva voce and notebook." (Jabeen \& Afzal, 2020).

Hal yang serupa juga ditemukan pada penelitian yang dilakukan oleh Ekeyi (2013) yang menuliskan,

"In conclusion, secondary school students reacted differently when instructed using the methods of demonstration and traditional lecture. In the traditional lecture group, the output of students is lower than in the experimental group (demonstration method) because they studied the chosen concepts with difficulty."

Penelitian lain yang serupa juga ditemukan pada penelitian yang dilakukan oleh $\mathrm{N}$, Vijayakumari \& K, Umashree (2017) yang mengemukakan temuannya,

The study findings clearly show that the specially designed instructional material based on the Cooperative Learning Strategy has proven to be better than conventional Lecture Demonstration Method in the creation of Ecocentric Attitude among Secondary School 


\section{E-ISSH: 2656-940X 는 | Volume: 7 \\ P-ISSI: 2442-36TK Nomor : 1 \\ URL: jurnalideaspublishing.co.id \\ Bulan : Februari \\ Tahun : 2021}

students. Teachers should be educated in their teaching styles to follow creative teaching methods to provide opportunities for young potential students to develop a desirable attitude towards the environment."

Berdasarkan temuan dan kajian dari hasil penelitian di atas, maka dapat disimpulkan bahwa kemajuan teknologi informasi sangat berdampak positif bagi dunia pendidikan, terutama teknologi komputer baik dalam hal perangkat keras maupun lunaknya. Penelitian yang dilakukan peneliti saat ini, menggabungkan penggunaan media komputer interaktif dan metode demonstrasi pada siswa jenjang SD. Hal ini disebabkan hambatan dalam pembelajaran IPA biasanya terletak pada penggunaan media dan metode pembelajaran yang kurang menarik, menantang, dan menyenangkan. Akibatnya hanya $23 \%$ siswa yang mampu mencapai KKM dan potensi siswa belum berkembang secara maksimal. Tujuan penelitian ini tidak hanya berorientasi pada peningkatan hasil belajar tapi juga pada peran aktif siswa dalam pembelajaran dengan melakukaan kegiatan demonstrasi.

\section{Metode}

Penelitian ini adalah penelitian tindakan kelas (classroom action research) yang dilaksanakan di SDN Semper Timur 07, Jalan Kebantenan IV No 35, Kelurahan Semper Timur, Kecamatan Cilincing, Jakarta Utara. Subjek dalam penelitian ini adalah siswa-siswi kelas IV yang berjumlah 22 orang, terdiri dari 11 siswa laki-laki dan 11 siswi perempuan dengan objek penelitian muatan pelajaran Ilmu Pengetahuan Alam (IPA) tentang gaya. Penelitian ini berlangung di semester II, melalui dua siklus, masing-masing siklus menggunakan media komputer interkatif pada metode demonstrasi.

Metode demonstrasi merupakan metode mengajar dengan cara memperagakan barang, kejadian, aturan, dan urutan melakukan kegiatan, baik secara langsung maupun melalui penggunaan media pembelajaran yang sesuai dengan pokok bahasan atau materi yang diajarkan (Syah, 2003). Sedangkan Djamarah \& Zein (2002) mendefinisikan bahwa metode demonstrasi adalah metode yang dipakai untuk menunjukkan suatu proses atau cara kerja suatu benda yang terkait dengan bahan pelajaran.

Model yang digunakan dalam PTK ini adalah model proses siklus (putaran atau spiral) yang mengacu pada model PTK Stephen Kemmis, Robbin McTaggart dan Rhonda Nikon (Kemmis dkk., 2014). Pemilihan model ini karena dengan menggunakan model ini, apabila pada awal pelaksanaan tindakan ditemukan adanya kekurangan, maka perencanaan dan 


\section{Volume: 7 \\ Nomor : 1 \\ Bulan : Februari \\ Tahun : 2021

pelaksanaan perbaikan masih dapat dilanjutkan pada siklus berikutnya sampai target yang diinginkan tercapai.

Rancangan penelitian ini memiliki empat tahapan kegiatan pada setiap siklusnya, yaitu membuat rencana tindakan, melaksanakan tindakan, mengadakan pemantauan atau observasi, memberikan refleksi dan evaluasi untuk memperoleh sejauh mana pencapaian hasil yang diharapkan kemudian direvisi untuk melaksanakan tindakan pada siklus berikutnya. Pelaksanaan perbaikan pembelajaran ini dilakukan melalui prasiklus dan 2 siklus pada pembelajaran IPA. Setiap siklus perbaikan pembelajaran dialokasikan waktu 2 x 35 menit.

Teknik analisis data dalam penelitian ini menggunakan pengolahan data dengan teknik analisis kualitatif dan teknik analisis kuantitatif (Sugiono, 2008). Teknik analisis kualitatif fokus dalam mengukur kemampuan siswa terhadap materi yang telah diajarkan oleh guru. Data kualitatif diperoleh melalui nontes yang merupakan hasil observasi supervisor 2 selama penelitian berlangsung. Teknik analisis kuantitatif berkaitan dengan nilai dari hasil tes siswa ketika perbaikan pembelajaran dilaksanakan.

Data yang dikumpulkan pada masing-masing siklus kemudian dianalisis untuk mengetahui nilai rata-rata hasil belajar dan prosentase ketuntasan belajar siswa.

Tabel 1. Jadwal Penelitian Siklus

\begin{tabular}{|c|c|}
\hline Pertemuan & Hari/Tanggal \\
\hline 1 & $\begin{array}{l}\text { Prasiklus } \\
\text { "Gaya Merubah Arah Gerak Benda" }\end{array}$ \\
\hline 2 & $\begin{array}{l}\text { Siklus } 1 \\
\text { "Gaya Merubah Arah Gerak Benda" }\end{array}$ \\
\hline 3 & $\begin{array}{l}\text { Siklus } 2 \\
\text { "Gaya Merubah Bentuk Benda" } \\
\text { "Macam-Macam Gaya" }\end{array}$ \\
\hline
\end{tabular}




\section{Hasil}

Berikut disajikan data rekapitulasi hasil belajar siswa dengan inisial nama pada tahap prasiklus, siklus 1 , dan siklus 2 dalam bentuk grafik.

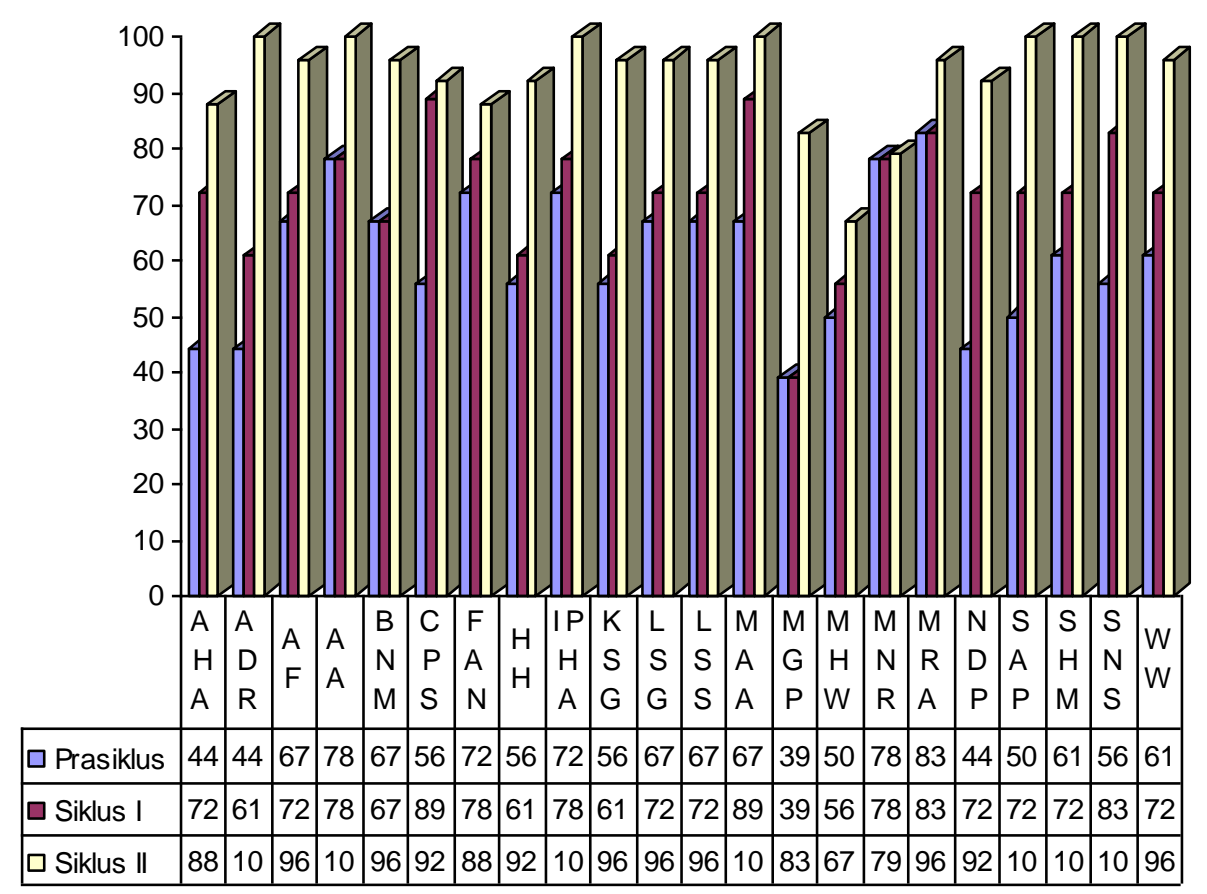

Grafik 1. Data Rekapitulasi Hasil Prasiklus, Siklus I, dan Siklus II

Berdasarkan grafik tersebut di atas dapat diketahui bahwa jumlah nilai siswa kelas IV SDN Semper Timur 07 Pagi Jakarta Utara pada tahap prasiklus adalah 1335, rata-rata kelas 60.68, nilai tertinggi 83, nilai terendah 39, prosentase ketuntasan KKM 23\%, prosentase ketidaktuntasan KKM 77\%, dengan kriteria ketuntasan minimal untuk pembelajaran IPA adalah 70. Pada tahap siklus 1 , jumlah nilai siswa adalah 1557 , rata-rata kelas 71.68 , nilai tertinggi 89, nilai terendah 39, prosentase ketuntasan KKM 73\%, prosentase ketidaktuntasan KKM 27\%, dengan kriteria ketuntasan minimal untuk pembelajaran IPA adalah 70. Pada tahap siklus II, jumlah nilai siswa adalah 2053, rata-rata kelas 93.32, nilai tertinggi 100, nilai terndah 67, prosentase ketuntasan KKM 95\%, prosentase ketidaktuntasan KKM 5\%, dengan kriteria ketuntasan minimal untuk pembelajaran IPA adalah 70. 


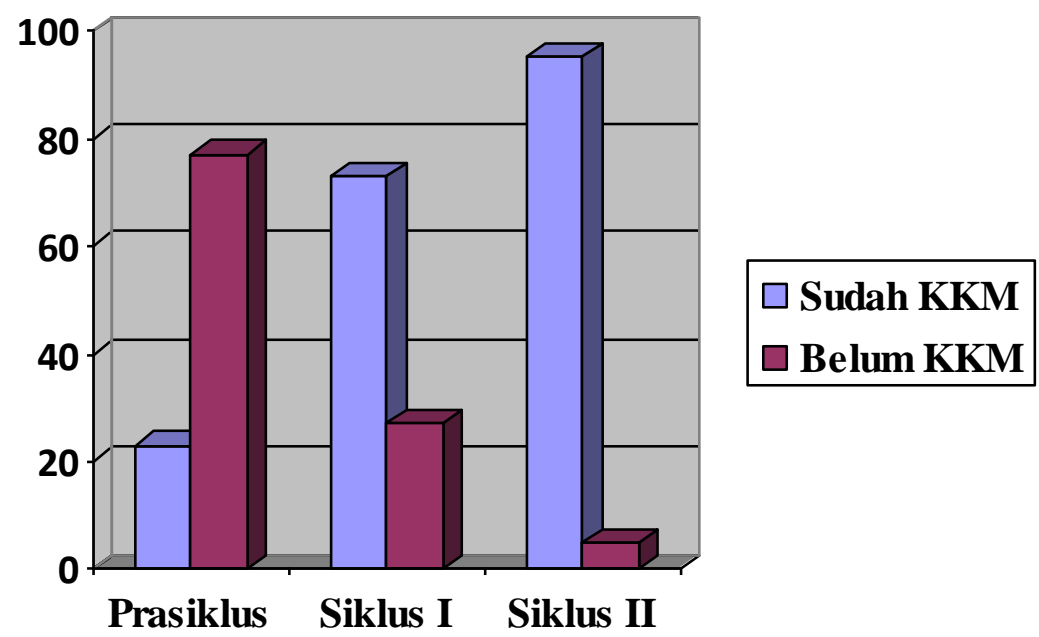

\section{Grafik 2: Rekapitulasi Hasil Tes IPA Prasiklus, Siklus 1, dan Siklus 2}

Berdasarkan hasil belajar siswa pada siklus 2, peneliti menyimpulkan bahwa nilai yang diperoleh siswa terus meningkat sehingga penelitian dapat dikatakan berhasil. Oleh karena itu, penelitain ini dicukupkan pada siklus 2 dan tidak perlu melanjutkan penelitian ke tahap siklus 3.

Peneliti berhasil mengubah suasana belajar di dalam kelas melalui penggunaan media komputer interaktif. Peneliti juga membangun suasana belajar yang aktif dan menyenangkan dengan melibatkan partisipasi siswa untuk memanfaatkan media yang tersedia dalam proses pembelajaran, sehingga lebih melekat dalam ingatan mereka.

Kegiatan belajar IPA tentang gaya menggunakan media komputer interaktif dengan metode demonstrasi, terbukti mampu meningkatkan hasil belajar siswa di kelas IV SDN Semper Timur 07 Pagi Jakarta Utara. Hasil belajar yanng diperoleh siswa meningkat secara signifikan, sehingga peneliti menyimpulkan bahwa penelitian tindakan kelas ini dinyatakan berhasil mampu meningkatkan hasil belajar siswa.

\section{Pembahasan}

Pelaksanaan penelitian tindakan kelas ini dilakukan dalam 2 siklus. Subjek yang diteliti adalah peserta didik kelas IV di SDN Semper Timur 07 Pagi, Jakarta Utara. Materi atau pokok bahasan yang diteliti yaitu materi gaya dengan menggunakan media komputer

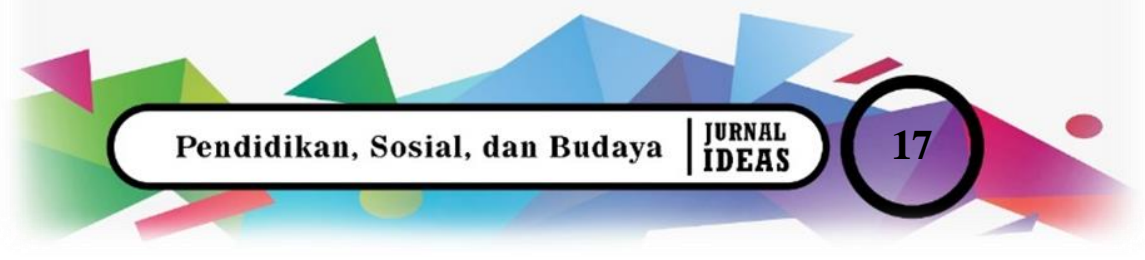




\section{E-ISSH: 2656-940X L \\ P-ISSH: 2442-367K Nomor : 1 \\ URL: jurnal.ideaspublishing.co.id $\quad \begin{aligned} & \text { Bulan : Febr } \\ & \text { Tahun : } 2021\end{aligned}$}

interaktif dan metode demonstrasi. Pada tahap prasiklus, hanya terdapat $23 \%$ siswa yang mampu mencapai nilai KKM 70.

Penyebab hasil belajar yang kurang memuaskan dan belum tercapainya nilai yang maksimal disebabkan hal-hal berikut.

a. Siswa kurang motivasi untuk mengikuti pelajaran IPA

b. Penggunaan alat peraga yang sangat minim

c. Pembelajaran kurang menarik dan monoton.

Dalam kegiatan perbaikan pembelajaran di siklus 1 dari perolehan nilai siswa sudah menunjukkan peningkatan walaupun belum cukup signifikan sehingga peneliti melanjutkan ke siklus 2. Hal ini merupakan dampak positif dari kegiatan perbaikan pembelajaran di siklus 1. Namun karena masih banyak siswa yang belum mendapatkan nilai 70 , maka peneliti dapat menarik kesimpulan, penyebab dari hal tersebut adalah sebagai berikut.

a. Masih belum optimalnya penggunaan media komputer interaktif dalam pembelajaran.

b. Belum maksimalnya penggunaan metode demonstrasi dalam pembelajaran.

c. Siswa masih malu dalam mendemonstrasikan aktivitas terkait materi pembelajaran.

Selanjutnya pada siklus 2 pembelajaran ini dianggap berhasil karena rata-rata nilai cukup besar dan siswa yang memilliki nilai di bawah 70 hanya 1 orang. Adapun langkahlangkah yang menyebabkan siswa mendapatkan hasil yang cukup besar adalah sebagai berikut.

a. Baik guru maupun siswa sudah terampil dalam menggunakan media komputer interaktif.

b. Setiap siswa memiliki kesempatan yang sama untuk mendemonstrasikan aktivitas pembelajaran.

c. Keinginan untuk bertanya lebih besar, karena dorongan motivasi yang diberikan guru.

d. Siswa lebih percaya diri dengan hasil jawabannya sendiri.

e. Guru sudah menguasai kelas, sehingga siswa konsentrasi pada muatan pelajaran yang sedang dipelajari.

Penelitian ini serupa dengan penelitian yang dilakukan oleh Sutarman (2016) terkait pembelajaran berbasis komputer model tutorial. Selain itu hasil penelitian ini juga memiliki kesamaan dengan penelitian yang dilakukan oleh Ermawati (2020) terkait pembelajaran dengan metode demontrasi. Namun peneliti menggabungkan penggunaan media komputer interaktif dan metode demontrasi dalam melaksanakan pembelajaran IPA di Kelas IV SDN Semper Timur 07. Dengan mengatasi kendala terkait pembelajaran IPA melalui penggunaan 


\section{Volume: 7 \\ Nomor : 1 \\ Bulan : Februari \\ Tahun : 2021

media komputer interaktif dengan metode demonstrasi, maka dapat tercapai hasil yang sangat tinggi. Hal tersebut disebabkan adanya motivasi dari guru untuk terus belajar dan memperbaiki kemampuan mengajarnya, sehingga berdampak pada peningkatan hasil belajar dan keaktifan siswa.

\section{Simpulan}

Penggunaan media komputer interaktif mampu meningkatkan minat belajar, motivasi, dan pemahaman siswa terhadap materi yang diberikan dengan tujuan utama meningkatkan hasil belajar siswa. Media komputer interaktif mempunyai peranan yang penting dalam meningkatkan hasil belajar IPA khususnya tentang gaya, seperti yang telah dibuktikan dengan hasil penelitian ini. Begitu pula dengan metode demonstrasi yang digunakan dalam pembelajaran IPA terkait materi gaya, terbukti dapat meningkatkan peran serta, rasa ingin tahu, dan keaktifan siswa. Pengembangan penelitian ini dapat diterapkan pada materi IPA lainnya dengan menggunakan aplikasi atau software yang tersedia di sekolah dan melibatkan partisipasi aktif siswa dalam pembelajaran.

\section{Daftar Rujukan}

Astra, G. N. W., Suarjana, I. M., \& Suwatra, I. I. W. (2013). Pengaruh model pembelajaran problem solving berbantuan media video pembelajaran matematika terhadap kemampuan pemecahan masalah siswa IV gugus IV kecamatan Sukasada. Jurnal Mimbar PGSD Universitas Pendidikan Ganesha, 1(1). https://ejournal.undiksha.ac.id/index.php/JJPGSD/article/view/1399/1260

Dwiqi, G. C. S., Sudatha, I. G. W., \& Sukmana, A. I. W. I. Y. (2020). Pengembangan multimedia pembelajaran interaktif mata pelajaran IPA untuk siswa SD kelas V. Jurnal Edutech Undiksha, 8(2), 33-48. https://doi.org/10.23887/jeu.v8i2.28934

Ekeyi, D. N. (2013). Effect of demonstration method of teaching on students ' achievement in agricultural science. World Journal of Education, 3(6), 1-7. https://doi.org/10.5430/wje.v3n6p1

Ermawati, : (2020). Peningkatan hasil belajar IPA melalui metode pembelajaran demonstrasi. Wahana Didaktika, 18, 30-38.

Fauyan, M. (2019). Developing interactive multimedia through ispring on Indonesian language learning with the insights of islamic values in Madrasah Ibtidaiyah. Al Ibtida. Jurnal Pendidikan Guru MI, 6(2), 177.

Hartini, S., Misbah, Dewantara, D., Oktovian, R. A., \& Aisyah, N. (2017). Developing learning media using online prezi into materials about optical equipments. Jurnal Pendidikan IPA Indonesia, 6(2), 313-317.

Hermawan. (2009). Pengembangan model pembelajaran berbasis komputer (teori dan praktek). Kurikulum dan Teknologi Pendidikan, Fakultas Ilmu Pendidika, Universitas Pendidikan Indonesia. 
E-ISSH: 2656-940X

Volume: 7

P-ISSH: 2442-367K

Nomor : 1

URL: jurnalideaspublishing.co.id

Bulan : Februari

Tahun : 2021

Jabeen, F., \& Afzal, M. T. (2020). Effect of simulated chemistry practicals on students ' performance at secondary school level. Journal of Education and Educational Development, 7(1), 119-139. https://doi.org/DOI:

http://dx.doi.org/10.22555/joeed.v7i1.2600

Kemmis, S., Robin, M., \& Nixon, R. (2014). The action research planner (1st ed.). Springer.

N, Vijayakumari, S., \& K, Umashree, D. (2017). Effectiveness of cooperative learning and lecture demonstration method on developing ecocentric attitude among secondary school students. I-Manager's Journal o n School Educational Technology, 12(3), 44-53.

Nopriyanti, N., \& Sudira, P. (2015). Pengembangan multimedia pembelajaran interaktif kompetensi dasar pemasangan sistem penerangan dan wiring kelistrikan di SMK. Jurnal Pendidikan Vokasi, 5(2).

Oktafiani, D., Nulhakim, L., \& Alamsyah, T. P. (2020). Pengembangan media pembelajaran IPA berbasis multimedia interaktif menggunakan Adobe Flash pada Kelas IV. Mimbar PGSD Undiksha, 8(3), 527-540.

Pamungkas, A. S., Ihsanudin, I., Novaliyosi, N., \& Yandari, I. A. V. (2018). Video pembelajaran berbasis sparkol videoscribe: Inovasi pada perkuliahan sejarah matematika. Jurnal Pendidikan Matematika, 2(2), 127.

Praditya, D. (2019). Multimedia pembelajaran dengan evaluasi instructional game matematika siswa kelas VII SMPLB-B Negeri 1 Buleleng. Jurnal Edutech Undiksha, 6(1), 66-76.

Prasetyo, G., \& Prasojo, L. D. (2016). Pengembangan adobe flash pada pembelajaran tematik integratif berbasis scientific approach subtema indahnya peninggalan sejarah. Jurnal Prima Edukasia, 4(1), 54.

Putra, L. D., \& Ishartiwi. (2015). Pengembangan multimedia pembelajaran interaktif mengenal angka dan huruf untuk anak usia dini. Jurnal Inovasi Teknologi Pendidikan, 2(2), 169-178.

Rahmi, M. S. M., Budiman, M. A., \& Widyaningrum, A. (2019). Pengembangan media pembelajaran interaktif macromedia flash 8 pada pembelajaran tematik tema pengalamanku. International Journal Of Elementary Education, 3(2), 178-185.

Rusdewanti, P. P., \& Gafur, A. (2014). Pengembangan media pembelajaran interaktif seni musik untuk siswa SMP. Jurnal Inovasi Teknologi Pendidikan, 1(2), 153-164.

Sagala, S. (2006). Konsep dan makna pembelajaran. Alfabeta.

Sugiono. (2008). Metode penelitian pendididikan (pendekatan kuantitatif, kualitatif dan $R \&$ ). Alfabeta.

Sutarman, A. (2016). Pemanfaatan pembelajaran berbasis komputer model CD interaktif tutorial untuk meningkatkan hasil belajar. Jurnal Penelitian Dan Pembelajaran IPA, 2(1), 81-98.

Widiana, I. N. A., Murda, I. N., \& Margunayasa, I. G. (2015). Pengaruh model pembelajaran kooperatif tipe jigsaw 1 dengan bantuan media konkret terhadap hasil belajar IPA kelas V di SD gugus XIV, kecamatana Buleleng tahun pelajaran 2014/2015. Mimbar PGSD Universitas Pendidikan Ganesha, 3(1).

Widiara, I. K. (2018). Blended learning sebagai alternatif pembelajaran di era digital. Jurnal Purwadita, 2(2), 50-56. 